\title{
The Quest for Workers' Social Security in the era of Globalized Labour Arrangements: a Synthesis of Labour Studies
}

\author{
Danstan Mukono \\ Assistant Lecturer, Department of Sociology \\ University of Dar Es Salaam, Tanzania \\ Email:mukono5@hotmail.com
}

Received: February 02, 2016 Accepted: February 14, 2016 Published: February 27, 2016

doi:10.5296/jsr.v7i1.9017 URL: http://dx.doi.org/10.5296/jsr.v7i1.9017

\begin{abstract}
International social change has generated scholarly debates on the process and impacts of globalization on the labour arrangement with specific attention to the livelihood of workers. In this review of interdisciplinary research, we put together and review from the labour and social security research papers analysing the trend and dimensions of labour flexibility in the contemporary society and discuss them in a more reflective way to make it available with a purpose of establishing research interests in the sociology of work and social security. We also delineate various forms of social insecurities that are dominant in different organization by drawing evidence from a multiple of studies conducted both from developed and developing countries. Finally, we points out the likely policy implications and recommend that the concern is to address inequalities and determining what socio-economic security forms that are supportive.
\end{abstract}

Keywords: Social security, Globalisation, Labour flexibility, Class 
1. Introduction and Background to the Global Labour Flexibility in Production Systems

The period before global flexibility, that of 1945 up to 1975 , that is characterized by a closed-economy model in that international trade took place primarily among countries with similar levels of labour security and thus cost structure, and an international division of labour based on "underdeveloped" countries producing primarily goods while "developed" countries producing manufactured goods and services (Standing 2002). In developing countries, the practices reflected state socialism that's put on its agenda the question of improving labour by fully replicating the decommodification of labour. For instance, in Tanzania under Socialism and Self-reliance enacted Social Security Act of 1964 (Mukono, 2012). Increasingly, the state had to put in place pro-workers regulations, rules that inwardly increased avenues for associations, removing of tyranny managerial systems and emphasizing at a more ideological level the egalitarian relations (Standing 2001; Shivji 1986). So to say, the power of workers to negotiate their remunerations and social protection was undeniably strong as both workers and unions pressed it.

It is not surprising that from the mid of 1970s was the turning point in the great transformation from that of social centred labour to a more economic centred labour (homo economicus). That is, the modern era operating on the assumption that everything should work on the logic of the market. Globalization as a process in terms of labour emphasizes the process of responsibilising people, to put it into context, implying a more subtle mechanism of the state and firms to withdraw from the provision of social protection. In the view of the social scientists, to put it concisely, globalization as a concept has been heard in the words of many in the media, policy makers, and scientists have tried to explain the acceleration of social and economic processes and the changes in the employment careers in the recent past (Waters 2001). To consider Mills and Blossfeld (2005), characterization, globalization has four notable aspects that relates to labour arrangement, namely; the internationalization of market and decline of national borders, rapid intensification of competition between firm based on deregulation, privatization and liberalization within national states, the accelerated diffusion of knowledge and spread of global information and technologies (ICTs), and the rising importance of markets and their dependants on random shocks occurring at any place in the world.

To be more specific, in this paper, we consider this process as the institutionalization of neoliberalism that unrelentingly claims flexible labour market as healthy and expansive that in the long run has a positive impact on workers. It is worth bearing in mind that the protagonists of flexible labour arrangement stress that this process is more profitable and its dictates will push more people to compete within a more free market with a full of 'opportunities' (Mukono 2012). To make the point more precisely, the global arrangement of labour believes in self-driven efforts and the role of the employer or the state is kept very minimal. Mukono (2012) comes closer to Shivji's (2009) claim that market practices, private enterprises that do accumulation, are becoming increasingly significant in welfare states. Guy Standing (2008c:39) observation evidently summarizes the situation by noting that 'the world is in the midst of a global transformation, reflecting the painful creation of a global market society. Equally important is that globalization is the disembedded phase, in which 
inequalities and insecurities multiply because of dismantling of the national systems of regulation, social protection and redistribution."

To consider again globalization, the global mechanism implies the increasing of capital and labour mobility, forcing firms continuously adjust, but these global developments are generating an unprecedented level of structural uncertainty in modern societies as it will be discussed in this paper. This suffices as an illustration that the transformations associated with the global flexibility have paved the way for employment flexibility, for instance, in the form of weakening of dismissal protection and diffusion of fixed-term contracts, part-time work and semi-independent forms of employment (Furugori 1993; Castells 2000; Chung 2009; Sverke et al, 2006).

The picture thus provided from the review is an observation that global flexibility in production systems does emphasis on individual freedom and less on collective action or the collective action by the worker in the production systems. Able to reflect upon, the main thesis of global flexibility is that of increasing integration of the world economy (through growing international trade, investment and financial flows) has robbed national governments of the power to pursue economic and social policies of their own choosing (Holden 2003). Analogously to Holden, Mishra's observation is that increase in the mobility of capital has triggered governments into 'race to the bottom' on its social policies; the governments have to respond to the international demand of receiving investors by creating a better environment by lowering taxation, lowering inflation and flexible labour markets (Mishra 1999).

Stressing that, Holden shows further that in the process of global flexibility, the welfare is residualised as a result of reductions in public expenditure forcing a move to more individual responsibility and private provision (Holden 2003). In the view of Holden, which is convincing, note that the ideas of globalization perform a powerful legitimate role; it enables the governments to implement unpopular policies by arguing that they have no choice (Holden 2003:306, Burnham 1997). Holden further demonstrates that continuous full -time work is becoming less frequent instead 'non-standard' work relations such as part-time work, fixed term contracts and marginal work are gaining importance (Holden 2003). This brings us to Mukono's observation from his study among casual cleaners at the University of Dar es Salaam; evidently tell us that public institutions are not immune in the process of embracing market-driven logic (Mukono 2012).

Breen (1997), cogently deciphers the fact that for employers in modern societies leads to the attraction of long commitments decline due to the volatility of labour, capital, commodity, and financial markets. Companies are responding to this event by transferring market risks to their employees, in his view he regards this process as 'recommodification of risks'. Breen observations intently also articulates of "contingent asymmetric commitment" referring to employers having an option for withdrawal from employment contracts at any time and employees have no other choice than to accept the decision being made by the owners of the firm/organizations.

With these introductory remarks, worth reading, the objective of this paper is to review and discuss with evidences from published studies to show the way growth of global labour 
flexibility in the production system and labour arrangement has affected social security. Attention is first made to shed light on the historical background of global flexibility in the production system and labour arrangement In the course of discussion an attempt is to delineate the rationale behind labour flexibility. What is crucial in this paper is the way on which the practice has affected social security within the process of arranging and organizing labour in the name of global labour flexibility. Evidence is drawn from various literature which analyses the subject of global labour flexibility by partly borrowing some of the scholarly examples which picture out the way the market forces play the role of enforcing the mechanisms of labour flexible arrangement. The main findings of this paper drew heavily from secondary data after an intensive review of literature by focusing on contemporary labour practices and the welfare of the people who are falling victims of structural inequality as a result of flexible labour arrangement. Surely, this helps to understand the problem faced by casual workers in the global labour flexibility with specific attention to Tanzania where such studies are still unknown.

\section{Global Flexibility Production Strategies}

Consistent with earlier remarks, Holden and Sverke et al have succinctly noted that the global flexibility in the production system and labour market arrangements has put in place various flexibility strategies of which the firms and companies can apply to meet the changing demands (Holden 2003; Sverke et al, 2006). These strategies are central in realizing productivity and profitability, but at the same time exploit the workers who pay the cost of the firm/organizations. It is important to mention that the process of labour flexibility goes unwittingly marginalizing workers into the chains of social insecurity and spearheading the war of all-against-all or on the words of Herbert Spencer "the survival of the fittest" of which Social Darwinism finds its way for self-responsibilization. Rightly so, the immediate observations, we deduce from this process, is the experience of increasing social insecurity and neglect of social responsibility and social solidarity among employers and the state as a basis for sustainable social protection.

Clearly implied, our review clearly shows that labour flexibility is more strategic to operationalize the philosophy of self-driven market logic with the aim of reaping more profits. Ofreneo (2002) and van de Hoeven (2002) portrait that several labour flexibility strategies which are dominant in today's production systems are the evidence of social organization of global labour flexibility. The duo enumerates six typology of flexibility which are as follows; first, is numerical flexibility, in this the companies have the option to adjust the number of employees through fixed-term contracts or layoffs, second, is externalization which means the outsourcing of certain tasks by subcontracting self-employed people who do not get employment contract. Third, is wage flexibility, this depicts the extent to which the employers have a range for adjustment of wages or benefits to changing market conditions. Fourth, is temporal flexibility implying the option for employers to adjust time, these are hours or months that the worker expects to spend on production. The fifth is the functional flexibility that is the power of employers to take over a wide spectrum of tasks by means of training and further education as well as incentive system. Lastly, is organizational flexibility, this reflects more turnover of firms, more use of sub-contracting and production chains and a tendency to 
contract the employment function (Ofreneo 2002; van der Hoeven 2002; in Auebach 2005:2).

Elaborating upon our review of the literature, it suggests that the first four and the last flexibilization strategies that leads to less-favorable labour situation for employees, and some of them also has influenced the risk of unemployment (Holden 2003, Sverke et al,. 2006, Mkenda 2005). Studies by Standing (2007; 2008) and Holden (2003) consistently shows that people are found in employment forms with a higher level of uncertainty than a permanent, average paid, socially secured a full-time job that is precarious. This shows that this is nothing but rather an atomization process of excluding the workers from the social fabric of deserving social protection and being penalized and tied to the market forces with unbearable power to withstand the social insecurities therewith.

The global flexibility in production and arrangement as Breen (1997) and Benardi (2000) observes have culminated into various types of uncertainty, namely; economic uncertaintyfacing the people who are working and not paid well, and temporal uncertainty. This is facing people who are working on the basis of fixed- term contracts, and social uncertainty, this is of more result of public social security arrangements like unemployment benefits are missing. In Beck's opinion, "a new form of risk breaks up with the logic of class structure", Beck further support that globalization has caused a shift from national risks towards those global risks in which poverty and unemployment correspond less and less class stereotype (Beck 2000a;153). Breen (1997), words tactfully surmise that 'labour market flexibilization fosters further discriminations by concentrating uncertainties on groups that are already used to having a weak position on the labour market, like unskilled workers'. What is crucial to Breen observation is that this process of labour flexibility is increasingly resulting into massive social inequalities and the suffering of the workers, caged into socially insecure working environment and is likely to become disposable at any time.

\section{Does the Issue of Class matter in the era of Global labour flexibility?}

This brings us to sociological concern which has been also studying people's location on the social structure of inequality. In more precise summary, protagonists of neoliberal policies claim that the era of global labour flexibility denotes the end of history and ideology ala Fukuyama. To put it into the words of Margret Thatcher, who strongly opposed the social organization of labour by stating that we are no longer social in nature rather driven by individualistic psyche and minimally attached to family (Harvey 2005). As no surprise, talking class issues is becoming bitter and archaic among defender of market-driven logic in the labour arena. Nevertheless, our perusal of the evidence so far gathered from the review of these various labour-related studies reminds us the importance of reflecting and show if the classical conception of class is still the same or not? If not, what specific classes are emerging and what are specific features which differentiate them and how each class is socially positioned in terms of social security within the labour arrangement. Our review has benefited much from Guy Standing categorization which provides an eye opener and starts to question these issues which are crucial but lost academic attention. Standing put nicely the arguments that prior to flexible labour market people were describing themselves in class terms, by the way they dresses, talk and discuss matters on their lived experiences. 
According to Standing (2013) class has not disappeared. Standing originality is of the view that 'instead, a more fragmented global class structure has emerged along a more flexible open labour market. Standing who adamantly call for radically egalitarian normative principles have identified the ideal type following Max Weber of new class relations. Despite the cause of these classes in developing countries to differ from those of western capitalist countries, yet we think that as earlier on pointed out, we need to start questioning this issue that is dominant in the neoliberal labour arrangement. Consistently with his interpretation Standing maintains that the old class still persisting but on top of those he identifies seven groups as follows;

At the peak is an elite class, this consist a small number of oddly rich group who are controlling the world whose richness is more celebrated to have billions of dollars. Elite class power is hegemonic in terms of influencing government policies and purports their own self-interest to be mirrored in every aspect of social life. Indeed, stated concisely, elite class believes and invest in philanthropic philosophy, of which are more paternalistic in nature as they give a peanut of their dispossessed wealth to the poor who deemed in need of salvation and mercy of the rich who are the few selected in the kingdom of richness in the capitalist society. Bill Gates and Melinda Gates, Rockefeller Family are the champions of philanthrocapitalism to it into Thompson's words (Thompson, 2014).

Beneath is the salaried class, this is a more known group of people attached to a more full-time employment, the sentiments and ambitions of some of them are struggling to the social ladder of the elite class. Standing clearly points out that most of them are enjoying the paraphernalia of their kind, fully covered with their pension, paid leave and related employment benefits funded by the state. It is important to mention that this class is more concentrated in large corporations, government agencies and public administration, and civil services. However, studies show that salaried are few, as it is a small segment of the employee who accommodated within the state based employed and few in private organization and Tanzania is not unique on this as it is only not more than 3 percent of employees on pensionable schemes.

Alongside the salaried is the proficians class, this is jumble of professionals and technicians, these are the group of minority of people trained with several skills which are found within the labour market. They are likely to earn high income on contract, who presumably works as consultants or what Standing (2013) call them "independent own-account workers". Standing further explain the distinctive characteristics of proficians with expectations and desire to move around various work without being enchained in permanent entitlement of full-time employability in a single employer. What matters for this group of people is to find where green pastures are available to them. It's also undeniable truth that this group of people is socially insecure in the sense that they are not integrated into state based social protection. Our experiences show that most of them depend on meandering around the exploitation of the people (especially graduates) who are seeking also temporal jobs and are being substandard per diem and consultancy fees justified in their proposal write-up and sometimes as Standing put it well they involves in tax evasion. 


\section{Mll Macrothink}

Journal of Sociological Research

ISSN 1948-5468

2016, Vol. 7, No. 1

The other group is core workers' class; a review of literature from sociological studies, show that this is a long and historical renown of people whom referred as proletariat or working class since the rise of industrialization process in Western Europe. Because of their long match struggle with the highest level of destitution, the state sought to remedy the situation by providing the social welfare. The era of labour decommodification to use Holden's phrase, those in full-time regular, unionized, and manual skills of which core workers were/are the part of it enjoyed the state based welfare. We learn a good example from Tanzania from the stipulation of the Employment Security Act of 1964 (Mukono 2012) which protected all types of employment. Conversely, with the turning of labour flexibility, we are experiencing a dwindling of this group of people, both in developed and developing countries since 1970s. Added to this, is more unsecure social income and their power to stand still to negotiate as we are going to see in the following sections in this paper. Standing points out evidence that "their agenda has lacked legitimacy" (in original). The role of core in the history of social movement in shaping the social welfare policy has no room, and we can dare strongly to state that the neoliberal labour arrangement has reduced core workers to an anti - politic machine by the state and the owners of the enterprise.

Below the core workers are the precariat class which includes the flexiworkers, the unemployed, and the detached (Standing 2002; 2013). In a classical conception of the word, we may explain this as custodian of the reserve army. Flexiworkers class, it comprises casual workers (Mukono 2012) ${ }^{1}$, outworkers, sub-contracted and contract labour, agency workers (Standing 2002) and domestic workers in our case migrated from rural poor households and more likely to be employed by the previous above class who pay them a small part of their income. The underlying assumption with the labour market flexibility is to cut the number of this class as a support of neoliberal policies claim that the economy will improve and accommodate them in flexible labour. To consider the studies by Mukono (2012) and Standing in his various works proves that the experience is contrary and seeing the increase of what Chachage (2006) termed them as a class of 'half backed education' or Standing see that majority of them without higher-level qualifications (Standing 2002:79). They continue to work without any substantial/real contract and they are encountering multitudes of the social insecurities as I discuss it later in this paper.

The unemployed class, the evidence indicates that their number has tremendously added. In the view of Standing unemployed class is experiencing suffering from labour market insecurity and the state is no longer investing in them and they are controlled and neoliberal labour markets push them in a state of destitution. Adding to their notch of insecurity is the negative image of the state that this class is irresponsible and lazy that needs controlling and punishment to develop self-directed mental attitudes of working which seems lacking among them. So to speak, dominant discourse among politicians and policy makers is that this group needs to implant in them an entrepreneurial attitude to uplift them from the traps of unemployment or to become homo economicus in the Focauldian sense of interpretation.

At the bottom is the detached class, this is a lumpen proletariat class in the Marxist sense of

\footnotetext{
${ }^{1}$ Mukono's case study of casual cleaners who are working at the University of Dar es Salaam is a classic example of the flexiworkers who increasingly piling up in the labour market.
} 
a class, it is a minority group of people who are growing and they hope to benefit from state based social welfare, is at the margin or not all existing. They are experiencing more destitution and unbearable poverty level, and state policy makers and politicians are uncomfortable with them, creating a bad image to the civilizing mission under the banner of neoliberalization of everything and Standing (2002:80) describe them right by stating that as a group seen by politicians as in need of "re-integration". The practical example from Tanzania is a number of beggars, "wapiga debe, , drug users, waste pickers (Mukono and Kamanyi 2013) who are found near the bus stands and public spaces. Standing argument is convincing that this group of people represents fear and as many above this group seems to being inclined to the detached group. The experience is that the detached class has become the victim of the state apparatus to clean them from the urban space and in the word of Wacquant (2010) are the incarcerated social class whose prison is their lived experiences and order of the day. Indeed Wacquant suggest that this process entails the emerging governmentality of social insecurity. A notable and current operation is that of cleaning up Dar es Salaam city in which machinga's (hawkers) have been forcefully removed in streets which are centrally for bus stands, along main roads, specifically traffic rights junctions and directed to find licensed and authorized business area.

Our review hitherto in this section has been at a quick glance to set up a base of understanding the extent to which different groups of people in the capitalist society, hereby referred to global labour flexibility society generates different types of social positions. This suggests a more broadening understanding of our horizon towards capturing differences or similarities in terms of social security/insecurity. Sociological categorization as this is convincing to suggest that is helpful in understanding neoliberal dictates of individual responsibility which curtails the social solidarity which put forward social humanity and justice at the forefront. As we will see in the next section, the state of social insecurities is more telling to the bottom three class categories. Data show that they are out of the scope of the state based social provisions and left to market-driven forces or if one is lucky to depend on unstable kin relations or informal groupings which have found some hope in traditional forms of social solidarity in Africa (Adesina 2008). ${ }^{3}$

\section{Global Flexibility and Social Security Structure}

Guy Standing, Wacquant and Mukono vividly points out the extent to which the global flexibility in production systems and labour arrangement has revised the socioeconomic security of the workers. In their analysis, observes the tremendous over an increase in the process of 'informalisation and causalization' in which seven types of insecurity (discussed fully later in this paper) processes affects the economic security of workers. They share the argument that the modern causalization that is taking place as part of globalization involves a steady restructuring of social income and labour recommodification, which many workers are finding that an increasing share of their remuneration is coming from money wages, which are relatively insecure as part of their social income. For instance, Mukono (2012)

\footnotetext{
${ }^{2}$ This is a group of youth who are jobless in urban areas who depending on receiving money from commuter bus conductors at bus stations by just chanting out the roots of the bus and its various destination areas, and most of them are victims of drug abuses.

3 Adesina Transformative Social Policy in post-neoliberal Africa context is a commendable effort towards using Africa based institution and practices to inform inclusive social protection instead of market-driven logic.
} 
proceeds with similar view by indicating that there is an increase of work which lack of standardization, of imposed discipline that of control by somebody in authority. Not only that, but also employees downside is unpredictability, being at someone's back-and call, insecure, dependent, patronized (Standing 2008:16).

Standing (2008) contends that, 'the context argument is that, the pressure of globalization, via flexibilization and informalisation of labour markets, produce an agenda for causalization'. Standing's view is that the neoliberal labour market plays the positive role to the side of the owners of the firms/organizations. In this process, it has led to more workers and families facing the downside, which means extensive social and economic insecurity. Furugori (1993) shared the similar views and pointed out the impact of flexible labour markets on the social security systems in Japan. Again, Breen (1997), for illustration, argues that the firms/organizations are downplaying the well-being of the workers to bear a lot of risks taken over by employers in the process of global flexibilization. We are observing downplaying of casual labourers' welfare with the power of employer in withdrawing of employment contracts at any time (Breen 1997; Mukono 2012). In a similar vein, Mukono (2012) revealed that the workers have no other choice than to accept this decision over their dismissal.

\subsection{Forms of Labour Security and Global Labour Flexibility}

In trying to identify and analyzing the impact of global flexibility in production systems and labour arrangement, I draw some of the insights from the whole process of social security in which one expects to see it. Analytical discussion made by Standing (2008) is well advanced in this paper. In normal circumstances workers expect from the labour market seven types of security coverage. These include, as pointed out by Standing, first, labour market security, under this, the worker expects to have adequate income-earning opportunities; at the macro level, this is through a government commitment to full Employment. Second is Employment security, in which the worker has protection against arbitrary dismissal, regulations on hiring and firing, imposition of costs on the employer for failing to adhere to the rules. Third, is Job security, this explains the ability and opportunity for the worker to retain a niche, an occupation per career plus barrier to skill dilution, and opportunities for upward mobility in terms of status and income. Fourth, is work security that is the protection of workers against accidents and illness at work; such as health and safety regulations, limits on working time, unsociable hours, and night work for women as well as compensation for mishaps. The fifth is skill reproduction security in which there is a good opportunity for a worker to gain and retain skills, through apprenticeships, employment training as well as an opportunity to make use of competencies. Sixth, is income security, this signifies for the assurance of worker's adequate and stable income protection through minimum wage machinery, wage indexation, comprehensive social security, progressive taxation to reduce inequality and supplement those with low-income, and lastly, is representation security, this is for the worker to have power for possessing a collective voice in labour market, through independent trade unions, with the right to strike, bargaining power, participation in decision related to their work condition (Standing 2008:18).

The above forms of security, workers enjoyed them during the era of Keynesianism modal 
and state based socialist welfare by providing full employment by the state was unquestionable and in this period in the views of many scholars see it as a period of labour decommodification (Standing 2007; Holden 2003; Mukono 2012). Workers received full economic security, however Standing is critical of it by arguing that it contained structural inequalities (Standing 2008:17), of which women were ill-treated in their work. As he proceeds to explain, the era of pre-globalization experienced the advancement of all seven forms of labour security as explained earlier in this paper, the period was that of 1945 up to 1975.In case of Tanzania, Employment Security Act of 1964 protected them and the state provided provisions and guidelines for the protection of both permanent and temporal employees (Mukono, 2012:2).

As it is now commonly observed, the era of global labour flexibility in which others term it as an era of re-commodification, workers no longer enjoy the aforesaid forms of social security. In the word of Holden (2003), Schumpeterian workfare state (SWS) is influencing the era of global flexibility where its modal seeks to promote product, process, organizational and market innovation in open economies in to strengthen as far as possible the structural competitiveness of the national economy by intervening on the supply side, and to subordinate social policy to the needs of competition (Jassop 1994; in Holden 2003:307. Mukono (2012:1) term it as 'an era of social insecurity and vulnerability that workers' aspirations for full and productive employment become dismissed under the era of neoliberalism both in terms of policies and practices'. This is strongly opposing the labour arrangement which emphasizes the work related social protection by claiming that it is an obstacle to the growth of the economy and obscure private capital to regenerate.

\subsection{Global Labour Flexibility and the Question of Social Income}

The main emphasis of this modal is on innovation and flexibility. Under this, the state, as argued by Holden (2003) is thus becoming a 'commodifying agent' rather than a 'decommodifying agent'. Thus, the era of global labour flexibility in production systems and labour arrangements has resulted into various global trends in labour related insecurities of that outsourcing is one of the manifestations, labour recommodification that determine the direction of social policy on welfare (Standing 2005; 2007; 2008). In his opinion, Standing in various works proposes ideal model to analyze and see the extent to which the global labour flexibility in production and labour arrangement has affected social security one need to take into account the whole aspect of Social income. Guy Standing (2001) proposes the Social Income formula as follows;

\section{$\mathrm{SI}=\mathrm{SP}+\mathrm{W}+\mathrm{CB}+\mathrm{EB}+\mathrm{SB}+\mathrm{PB}$}

Where SI is the individual's total social Income, SP is self-production, W is the money wage or income or income received from work, $\mathrm{CB}$ is the value of benefits or support provided by the family, kin or local community, EB is the amount of benefits provided by the enterprise in which the person might be working, SB is value of the state benefits, in terms of insurance or other transfers, the value of social services, and PB is private income, gained through investment and private insurance (Standing 2008:18). 
Standing (2001), further, decomposes the above social Income formula into;

$\mathrm{SI}=\mathrm{SP}+\left(\mathrm{W}_{\mathrm{b}}+\mathrm{W}_{\mathrm{f}}\right)+(\mathbf{F} \mathrm{T}+\mathrm{LT})+(\mathrm{NWB}+\mathrm{IB})+(\mathrm{C}+\mathrm{IS}+\mathrm{D})+\mathrm{PB}$

Where $\mathrm{W}_{\mathrm{b}}$ is the base or fixed wage, $\mathrm{W}_{\mathrm{f}}$ is the flexible part of the wage (bonuses), FT are family transfers, LT are local community transfers, NWB are non-wage benefits provided by firms, IB are contingency, insurance type benefits provided by firms to their worker, $\mathrm{C}$ are universal state benefits, IS are insurance based income transfers from the state in case of contingency needs and D are discretionary, means-tested transfers from the state (Standing 2008:18). By looking in this decomposition, we are able to analyze and assess how the prevailing pattern of remuneration indicates the degree to which a person's labour is commodified (ibid). But in the era of global flexibility in the production system and labour arrangement, the more secure of the elements of SI is eroding with institutional intervention, legislation, the more workers find themselves in insecure or conditional on the performance of labour is growing in relative term (Standing 2008:18-19).

The protection system with regard to employment for instance, in Western Europe designed during the welfare state guided by Keynesianism modal and weakened under neoliberal labour market. The global flexibility in the production system and labour arrangement constrains the restructuring of social income; hence, this has resulted into intensification of income insecurity (Chung 2009; Standing 2007; 2008). The shift is on money wages in which, this encompasses the processes of re-commodification, the entitlement earlier provided by the enterprise, state benefits weakening.

In this way, it has been observed that even the non-wages benefit like sick benefit, maternity benefit and the like, these are no longer the major concern and the processes is constrained by the pattern of unequal distribution with regard to one's work position (Standing 2008:19). Some examples are such that a worker who falls ill; the employer is not of his concern to look for the employee. Then, if one day the worker loses a job, no any unemployment benefit available outside to accommodate him or her. Standing (2008) and closely noted by Mukono (2012) argues that this has accelerated toward the growth of systematic insecurities confronting labour arrangement in the era of global flexibility. In his study among casual labourers who work with cleaning companies at the University of Dar es Salaam, Mukono (2012) also identified employment, income and wages, representation, work and skill reproduction insecurities the dominant problem. These types of social insecurities are discussed in details in the following section.

Standing ${ }^{4}$ continues to delineate the impact of global flexibility in production and labour arrangement, which has resulted in the emergence of class structure due to fragmented structure. Below this, there is the different group of people having different entitlement analyzed in terms of the elements found in the social income. The regulatory and protective systems are no longer on their side (Holden 2003; Standing 2008). He identifies seven strata, namely elite, proficians, salariat, care workers, flexiworkers, unemployed and the detached

\footnotetext{
${ }^{4}$ Standing (2008), shows more classic examples where he provides an analyses of the ILO's institutional change has become the agent of globalization and even the production system and labour arrangement of its employees are facing the similar trends of insecurities
} 
category.

\subsection{Socio-Economic Insecurity and Global Labour Flexibility}

Subsequent elaboration on the general discussion in the previous section of this paper on the issues of global flexibility in the production system and labour arrangement leads us for a discussion of the forms of insecurities ${ }^{5}$ which have emanated from this process. The next sections are the highlights and brief discussion of the seven forms of insecurities. World Development Report (WDR) of 2000/2001 focuses on social insecurity by adopting the concept of risk and vulnerability (Moser 2001:361). The issue of risk is at the core of its approach, insecurity is defined as exposure to risk, while the vulnerability is a resulting possibility, or outcome, in terms of decline in well-being (ibid, 2001).

From what the paper has discussed in a general way, we need also to have a focus on the state of employees who are found in work where there are little and well-regulated rules which hold much attention to the working conditions and social well-being of the worker. Under this part, seven types of insecurities will be discussed, namely; Job insecurity, Wage insecurity, Work insecurity, skills reproduction insecurity, employment insecurity, representation or unionization insecurity, and income insecurity which is the order of the day for people who are working under the policies of labour market flexibility specifically falling under the category under this discussion. Yet, the findings from labour studies convinces that the speed of labour market flexibility is not proportional to dynamics of policies of social security schemes which leave the overwhelmed group of individuals under the threats which are direct result of the market forces and its associated child of labour market flexibility.

\subsubsection{Job insecurity}

Some scholars have discussed job insecurity and identified its causes and associated effects to particular employees (Greenhalg \& Rosenblatt 1998, Pearce 1998, Mohr 2000, Borg and Elizur 1992, Hellgren, Sverke, Isakson 1999, Louis-Guirin 1999; Sverke et al., 2006). Greenhalg and Rosenblatt (1998), defines job insecurity as perceived powerless to maintain desired continuity in the threatened job situation (Greenhalg \& Rosenblatt 1998:438). Adding on that is the idea that it can be understood as one's expectations about continuity in a job situation. This definition is informed by behavioral theory where individual cognitive, perceptions are central unit of analysis.

Other scholars take the position informed by objective or measurable variable, among those is Pearce (1998), in where job insecurity is characterized by an independently determined probability/chance that workers will have the same job in the foreseeable future (Sverke, et al.,2006:34). The basic assumption in this objective definition as noted by Sverke et al., (2006), is that, individual who find themselves in the type of employment and or organizations classified as insecure experience more job insecurity than the case with

\footnotetext{
5 A critical discussion of these forms of insecurities is found in Mukono D (2012) Social Insecurity and Vulnerability in the Context of Neoliberalism: A Case study of Casual Cleaners in Cleaning Companies at the University of Dar es Salaam. Saarbücken, LAP LAMBERT Academic Publishing
} 
individuals who hold a safe type of employment or work for an organization deemed as safe, especially those employees with no specified contract and employed temporary and occasionally and seasonally employed.

The labour market flexibility has brought various types of job insecurity, Mohr (2000) succinctly identifies; first, is job insecurity as a state of public awareness which involves a high degree of unemployment in society, this experienced notably in third world countries and Tanzania in particular. Second, job insecurity at the company level, which levels of unstable and insecure condition in the organization, third, is acute job insecurity involving the concrete, subjective experience of threat to employment and finally, anticipation of job loss to situation where layoffs have already begun.

Many commentators have argued that the definition and measurement of job insecurity would benefit from including concerns about deteriorating employment conditions and career opportunities in addition to threats to imminent job loss (Sverke, et al., 2006). Here, we have various forms which emerge like cognitive job insecurity (likelihood of job loss) and effective job insecurity (fear of job loss) as discussed by Borg and Elizur (1992); in Sverke, et al., (2006). Again, we have quantitative job insecurity (worries about losing the job itself) and qualitative job insecurity (worries about losing important job features) as depicted by Hellgren, Sverke, \& Isakson (1999) in Sverke et al., (2006).

\subsubsection{Income Insecurity}

It has been indicated by ILO (2007) that the absolute number of the world's working poor earning no more than US\$2 a day has grown to 1.37 billion and argues that these same workers will have no access to social security; this is a result of labour market flexibility. Persons who have low status, especially those who perform manual labour jobs are more prone, the work they engages in work such as sweepers, docking, security guards who are rapidly increasing in developing countries they are encountering the problem of low-income and in this situation are more vulnerable. It has been argued that, as they are more dependent on their income which is not stable, they are increasing becoming insecure.

The employees with low-income cannot save any money that makes a loss of income more severe in neoliberal labour. This has been associated with low-level of education, resulting in fewer coping resources and strategies and study have shown people who are based to blue-collar jobs are highly insecure in terms of income which of course has implication on their social livelihood (Naswall \& De Witte, 2003; in Sverke, et al., 2006). Compared with this claim and Mukono (2012) study revealed a more devastating situation that casual cleaners are approximately paid not more than US\$1. 57. Living in a society that is institutionalizing commodity relation, that is, one need money to buy goods and service, added to them an insurmountable social ladder to climb.

\subsubsection{Skills reproduction Insecurity}

First, let's see what skills reproduction security means, according to Standing (2007), defines skill reproduction security as a good opportunity to gain and retain skills, through apprenticeship, employment training as well as opportunity to make use of competencies. It 
has been argued that those workers who are found in non-standard jobs of which Standing call them flexiworkers ${ }^{6}$ or sweat shops work, have less access to training, hence the likeliness to add more skills is limited and in most cases they are found in the work place which demands less skills. Again, their education level denies them the possibility of advancing further and when adding the aspect of income they receive, i.e. wages. This implies that, even their level to be upgraded and promoted remains impossible and likewise they are bound to remain within the similar job of which they're vulnerable and insecure because their skills are not meeting the requirement of employed somewhere in another good paying job.

\subsubsection{Employment Insecurity}

Lower education and skills is a dominant feature which increases the state of employment insecurity to increases among individuals who are having similar education level which is lower. It has been observed that, they have few options for alternative employment in the labour market, or the individual sense of employability, which increases the degree of dependence on the present job, and this makes the threat of unemployment more severe (Gallie et al., 1998; Schaufeli, 1992; Sverke, et al., 2004; in Sverke, et al., 2006). Studies show that the nature of the contract employees holds has contributed to the increase of employment insecurity, people with no contract or time limited contract let say one year or subcontract, they feel less part of the current employment especially those in part-time or temporary employees (Furugori, 1993, Barling \&Gallagher 1996).

\subsubsection{Representation /union membership insecurity}

Being a member of a union serves to protect the worker against actions by management that intend to act contrary to prescribe the terms of the employment contracts. It enhances the environment to protect the employee from any harm, mistreatment like firing the worker without prior notice, cut-off of employee's wages. Sverke et al., (2006) argue that the sense of powerlessness increases among workers who are working under temporary, part-time, non-standard as they don't have an Association or trade union on which they can channel their claims and dissatisfied work condition they face. They don't have a collective voice which is the mechanism which can help to affect management policies in favor of the employees. They lack this crucial instrument where to present their grievances and problem; the problem which they face remains an individual concern (Ashford et al., 1989; Hartley et al., 1991; in Sverke et al., 2006:11). This leads to experiencing uncertainty on one's future employment, again this impinges on the person's overall life situation as the economic aspect of employee is under threat. This is because at any time the employer has the power to terminate his/her current worker without any reasons, so longer the employer has decided to do so in favor of personal interest of which in most cases is based on economic profitability. Their claim is that of the need to sustain the company and operate on cost-effective way.

Similarly, Mkenda (2005) explains the issue of unionization in respect to workers, security in

\footnotetext{
${ }^{6}$ Flexiworkers as discussed by Standing (2007), these include a desperate group in non-regular work statuses, including all forms of casual workers, outworkers, and agency workers of which he characterize them as facing the all forms of labour insecurity.
} 
Tanzania; she states that unions serve an important function of being a voice of representation for the workers. Unions also serve to see that employers adhere to safety regulations and standards for employees, and they also take part in drafting labour contracts and conditions of service. Also, when the state sold its companies as the experiences of Structural Adjustment Programs suggests, unions can press for advance notice of layoffs or negotiate for an alternative package that can prevent or reduce the numbers to be laid off, such as early retirement or an attrition plan (see IUOE, 2002). Research also shows that unions are instrumental in collective bargaining. Given the important role that union's play, the degree of unionization of the workforce can be used as a proxy of the extent of job security of workers.

\subsubsection{Wage insecurity}

Available information on wage insecurity suggests that the wages that workers get from their jobs play a key role in not only enhancing efficiency, but also in providing incentive in doing work. If wages are too low, more often than not, the worker will put less effort as they reserve for moonlighting activities (Mkenda 2005:8). Some of the studies have identified that the workers with less education earn less than those with more education (ibid). This implies that with the labour market flexibility, less skilled workers are less remunerated and are likely to remain poor and hence their state of becoming more insecure increases. The wages which are being paid are merely meant for subsistence, because cannot realistically meet much of basic necessities of the worker and their dependant whom they have obligations to provide social support.

\subsubsection{Work Insecurities}

Loewenson $(2000)^{7}$, asserts that even across those dimensions, over the period of structural adjustment, where macroeconomic reforms have made job security much weaker, and have put competition between industrial production higher on the agenda, health and safety protections have really slipped. It is a lot more difficult for workers to enforce their rights, because they are worrying about their job security. Loewenson points out that "it has been argued that on paper, issues related to workplace security like health and safety issues on dangerous works, and the rights of the employee to get information about the resultant outcomes to be exposed to certain risks, but in practicability those rules and laws are absent and the possibility of the worker to face work insecurity is increasing". He goes on to point out that what you find in some cases is countervailing legislation in the labour law which says that if you refuse to obey a lawful order, you will be dismissed.

It is difficult for workers to assert their rights unless they have organized to defend their interests. If the unions offer a very strong collective protective framework, if they have trained their representatives, who not from the employer, but are a product of active working class struggle, and if they get some degree of backup from the state, then there is a higher level of enforcement of those rights. But where unionization is weaker, and workers don't

\footnotetext{
${ }^{7}$ Loewenson (2000) provides vivid explanations pertaining to work insecurity in relation to occupation health and safety, where the author shows clearly that what is being written in the paper is contrary to what is found in the ground, many workers are working under dangerous environment. He discusses all aspect of occupation health and safety as practised in sub-Saharan countries.
} 
have a strong union base to take action, then even where these rights exist on paper, they are not that well implemented in practice, because of fear of job loss (Loewenson 2000). Laws such as the right to refuse dangerous work is very poorly structured and they don't give workers enough protection and the social systems are quite weak to protect workers. Likewise, the findings show that there has not been a compensatory pickup of self-inspection in the private sector. There is just generally a decline in resource allocation in health and safety, together with more uncontrolled working processes (ibid 2000). The observation by Loewenson is not peculiar studies by Mukono and Mkenda in Tanzania clearly reveal the same problem. Informalisation and causalization of labour gives no room for employees to enjoy work security and employers curtail any possibility of having more strong solidarity in forms of unionization for workers to demand their rights.

\section{Conclusion}

From this labour studies, we learn that labour market insecurity has grown almost globally with higher unemployment, facing the retardation in the rate of employability. In view of many, and evidence drawn from various literature shows that employment insecurity is becoming higher and rising, with a growing proportion of those in the labour force insecure employment status and with more workers lacking employment protection (ILO 2004, 2005, Holden 2003). The various forms insecurities which have been noted are the major threat in the current global labour flexibility. In developing countries, and Tanzania in particular, the findings continue to show that things are worse as the market has taken over in the process of production system and labour arrangement under the name of flexibility. The paper accentuate that the dynamics are not matching with the running global trends and leaving the majority deprived and living in destitution and unemployment, rise of causalization and informalisation where the government no longer having the power for protecting and providing citizenship rights. It is then not surprising that everyone, especially at the bottom of the stratum is left on his or own to compete in the flexible labour arrangement with weakened institutional intervention. We stress that production systems and labour arrangement analysis to focus on its complexity as the majority are found in the informal sector and depending on the nature of production, probably even this category is under threat as Standing $(2008,2007)$ refers it as detached category which comprises the majority of people in the developing countries.

In regard to policy issues the paper suggests that the main concern to put emphasize in addressing inequalities and determining what socio-economic security firms which are supportive. The latter can be achieved by the national states concentrating on two key aspects, namely income security and representational security. Equally problematic is that the chain constraining the bargaining power of the workers, this review suggest to untie them in this era, where capital is left mobile and in this process the corporate taxes are lost away as these are likely to improve the state mechanisms to induce socio-economic security as a citizenship right as suggested by pro-workers' welfare. It is undeniably the fact that the state which is not investing in social security for its people is at risk of experiencing social unrest, which in turn entirely affects the socio-economic base upon which it depends. It is imperative to argue that until we realize the need of investing in people's social security, we are likely to encounter 
the most social deadlock of increasing social inequalities which seems to escalate. We maintain that social security which is just, fair and equitable is a thrill for a more stable society and more productive for each member of society, but also for the growth of the organization either being service based or product based. We close this paper by categorically stating that it is worth bearing in mind that there is a need not think of investing in workers' social security as a loss but rather as strategic venture towards sustainable organization and society in general.

\section{References}

Auerbach, P., Eugenia, M., and Pajes. C. ( 2005). Social Security Coverage and Labour market in Developing Countries.

Adesina, J.O. (2008). Transformative Social Policy in post-neoliberal African context: Enhancing social citizenship. Paper prepared for the RC19 Stockholm 2008 Annual Conference, 4-6 September, 2008.

Beck, U. (1999). World Risk Society: Cambridge, Polity Press.

Beck, U. (2000a). The Brave New World of work: Cambridge, Polity Press.

Breen, R. (1997). “Risk, Recommodification and Stratification” Sociology 31:473-489.

Burke, R. J., and Nelson, D. (1998). "Mergers and acquisitions, downsizing, and Privatization: A North American perspective”, in M. K. Gowing, J. D. Kraft, \& J. C. Quick (Eds.),The new organizational reality: Downsizing, restructuring, and revitalization

Burnham, P. (1997). "Globalization: States, markets and class Relations", Historical Materialism 1 (1): 150-60

Castells, M. (2000). The rise of Network Society. The Information Age: Oxford, Blackwell Publishers

Chachage, C.S.L (2006a). "Keynote Address: Why Tanzania Still Poor fortyyears after Independence", Dar es Salaam, TUKI

Chung, J. (2009). "Be More Flexible? : The effects of labour market flexibility on Unemployment on Developing Countries", Arizona State University.

De Witte, H., and Näswall, K. (2003). ""Objective" vs. "Subjective" job insecurity: Consequences of temporary work for job satisfaction and organizational commitment in four European countries'. Economic and Industrial Democracy, 24, 209-312.

Hartley, J., Jacobson, D., Klandermans, B., and van Vuuren, T. (1991). Job insecurity: Coping with jobs at risk. London: Sage.

Hellgren, J. Sverke, M., and Isaksson, K. 1999. " A two-dimensional approach to job insecurity: Consequences for employee attitudes and well-being". European JournalHolden, C. (2003) "Decommodification and the Workfare State", Political Studies Review: 2003 Vol. $1303-316$ 
International Labour Organization. (2004). Socio-economic Security programme, Economic Security for a better world. Geneva: ILO

International Labour Organization. (2005). Socio-economic Security programme: Economic Security for a better world. Geneva: ILO

International Labour Organization. (2007). Global Employment Trends: Brief, Geneva Jessop, B. (1994). "The Transition to Post-Fordism and Schumpeterian Workfare State" in R.

Burrows, and B. Loader (eds), Towards a Post- Fordism Welfare State. London, Routledge Kets de Vries, M. F. R., \& Balazs, K. (1997) "The downside of downsizing". Human Relations, 50, 11-50.

Loewenson, R. (2000) "Power and Pain: Worker Organization and workplace Safety in South Africa" The Political Economy of Worker Safety.Vol.21:11

Mishra, R. (1999). Globalization and the Welfare State, Cheltenham: Edward Elgar

Mkenda, K.B. 2005. “The impact of Globalization on Tanzania's Labour Market: Evidence from Manufacturing Sector": A paper prepared for a Policy dialogue for Accelerating Growth and Poverty Reduction in Tanzania, held at the Conference Hall, ESRF, on July $28^{\text {th }}, 2005$

Mohr, G. B. (2000). "The changing significance of different stressors after the announcement of bankruptcy: A longitudinal investigation with special emphasis on job insecurity". Journal of Organizational Behavior, 21, 337-359.

Moser, C. (2001). "Insecurity and Social Protection- Has the World Bank Got it Right?" In Journal of International Development, Vol.13, 361-368(2001) of Work and Organization Psychology, 8, 179-195.

Mukono, D. (2012). Social Insecurity and Vulnerability in the Context of Neoliberalism: A Case study of Casual Cleaners in Cleaning Companies at the University of Dar es Salaam. Saarbücken, LAP LAMBERT Academic Publishing

Mukono, D., \& E. Kamanyi. (2013). Urbanization Process and the plight of Waste Pickers and Machinga: The case study of Dar es Salaam. Saarbücken, LAP LAMBERT Academic Publishing

Pearce, J. L. (998). "Job insecurity is important, but not for the reasons you might think: The example of contingent workers". In C. L. Cooper \& D. M. Rousseau (Eds.), Trends in organizational behavior (Vol. 5, pp. 31-46): New York, NY: Wiley.

Shivji, I.G (1986). Law, State, and the working Class in Tanzania, London, James Curey

Shivji, I.G (2009). Accumulation in an African Periphery: A Theoretical Framework, Dar es Salaam: Mkuki na Nyota

Soskice, D. (1991). The institutional Infrastructure for International Competitiveness: A Comparative Analysis of the UK and German in Economics for New Europe, edited by A.B Atkinson, London, Macmillan 


\section{Macrothink}

Journal of Sociological Research

ISSN 1948-5468 2016, Vol. 7, No. 1

Standing, G (2001). Global Insecurity: Restructuring Social Income. http://www.bisnath.com/events/global_Tensions/standing.html,, retrieved: 2013-11-21:5:52 $\mathrm{PM}$

Standing, G. (2002). Beyond New Paternalism: Basic Security as Equality, London, verso

Standing, G. (2005). "Labour recommodification" keynote paper represented at the Karl Polanyi Conference, Istanbul, October 2005

Standing, G. (2005). Promoting Income Security as Right, London, Anthem Press

Standing, G. (2008a). "Economic insecurity Globalization Causalization: Threat or Promise"? Soc Ind Res (2008) 88:15-30

Standing, G. (2008b). "ILO: An Agency for Globalization?" Development and Change 39 (3): 355-388 (2008), Oxford, Blackwell Publishing

Standing, G. (2008c). Reviving Egalitarianism in the Global Transformation: Building Occupation Security Indian Journal of Human Development, Vol.2, No. 1, 2008

Thompson, C.B. (2014). Philanthrocapitalism: appropriation of Africa's genetic wealth. Review of African Political Economy, 41:141, 309-405, DO: 101080/03056244.2014.901946

Waters, M. (2001). Globalization, London: New York, Routledge

Wacquant, Loïc. (2010). Crafting the Neoliberal State: Workfare, Prisonfare, and Social Insecurity. Sociological Forum, Vol. 25, No. 2, June 2010 pp. 197-220 